\title{
PENGARUH GREEN MARKETING TERHADAP KEBERLANJUTAN LINGKUNGAN, PROFITABILITAS PERUSAHAAN DAN EKONOMI MASYARAKAT LOKAL
}

\author{
Yudi Setiaji \\ Dosen Sekolah Tinggi Pariwisata AMPTA Yogyakarta
}

\begin{abstract}
Issues and awareness of resource conservation and the environment must be able to motivate companies to compete in the market place. Conservation and environmental sustainability issues should force companies to adapt the strategic planning process at a new socioeconomic needs. Ecological considerations are relevant variables to achieve economic objectives through strategic green marketing concept (GMS) in the tourism business in a sustainable manner. In order to focus the development of green tourism is significant, it is the responsibility of the environment should be part of the agenda of the company, as well as an increased concern for environmental damage should be the concern of travelers, government and non-governmental organizations with a way to put pressure on the industry to have a framework that is environmentally responsible, establish codes of conduct, certification, ecolabelling, awards, and an alliance of green products.
\end{abstract}

Green Marketing Strategic significant effect and can improve the quality of the environment, corporate profitability and economic growth of local communities. Personal values in berpengruh company and can significantly improve the quality of the environment, corporate profitability and economic growth of local communities.

Environmental values and significantly influential organizations can improve the quality of the human environment, corporate profitability and economic growth of local communities. The role of government can have a significant effect and improve the quality of the environment, corporate profitability and economic growth of local communities.

Keyword: Environmental, Economic Communityand Its Profitability OfLokal GreenTourism Marketing

\section{LATAR BELAKANG MASALAH}

Indonesia merupakan salah satu negara yang memiliki potensi alam dan keaneka-ragaman budaya yang dapat dijadikan destinasi wisata. Pariwisata di negara ini semakin berkembang dan menjadi pendapatan devisa negara terbesar kedua setelah minyak bumi dan gas, ia menjadi salah satu generator penting dalam pembangunan ekonomi yang berdampak positif bagi kesejahteraan rakyat Indonesia pada umumnya dan masyarakat kawasan destinasi pada khususnya.

Namun, dalam perjalanannya kita menemui bahwa perkembangan pariwisata yang ada saat ini hanya memperhatikan sisi pendapatan secara ekonomi, para pengelola industri pariwisata melakukan over exploitation tanpa mempertimbangkan keterbatasan sumber daya, kelestarian lingkungan, pengembangan kualitas hidup, budaya dan kesejahteraan masyarakat lokal, akibatnya disana-sini banyak terjadi kerusakan lingkungan, pengurasan sumber 
daya, degradasi nilai-nilai budaya, serta komersialisasi nilai-nilai religius. Oleh karena itu setiap pemain bisnis pariwisata di negara ini harus dipaksa untuk membangun dan mengembangkan potensi lokal untuk dijadikan destinasi wisata unggulan berbasis kelestarian sumber daya, lingkungan dan budaya, agar pariwisata sebagai industri yang bersifat multidimensional dapat mengoptimalkan kemampuannya dalam mendina-misasi pertumbuhan sektor-sektor lainnya.

Isu dan kesadaran pelestarian sumber daya dan lingkungan harus dapat memotivikasi perusahaan berkompetisi dalam market place. Isu konservasi dan keberlanjutan lingkungan harus memaksa perusahaan untuk mengadaptasi proses perencanaan strategisnya pada suatu kebutuhan sosial ekonomi baru. Pertimbangan ekologi merupakan variabel yang relevan untuk mencapai tujuan ekonomi melalui konsep green marketing strategic (GMS) dalam bisnis pariwisata secara berkelanjutan (Polonsky, 2010)

Agar fokus pengembangan green tourism ini signifikan, maka tanggung jawab lingkungan harus menjadi bagian dari agenda perusahaan, demikian juga peningkatan kekhawatiran terhadap kerusakan lingkungan harus menjadi kepedulian dari wisatawan, pemerintah dan organisasi non-pemerintah dengan cara memberikan tekanan pada industri untuk memiliki kerangka kerja yang bertanggung jawab terhadap lingkungan, membentuk kode etik, sertifikasi, ekolabel, penghargaan, dan aliansi green produk (Clark, Kotchen \& Moore. 2003). Masalah utamanya adalah (1) apakah konsep ini benar-benar dapat diterima oleh pelaku bisnis pariwisata dan pasar mengingat perkembangan dunia yang semakin pesat yang nota bennya konsep green tourism ini sempat ditinggalkan, pelaku bisnis dan pasar lebih tertarik dengan kecanggihan teknologi terbaru ataupun gaya hidup serba metropolitan; (2) bagaimanakah sebuah perusahaan pariwisata (hotel, destinasi, dan atraksi wisata) dapat mengelola reputasi green dan seberapa cepat kemampuan menanggapi isu lingkungan; dan (3) apakah pesan atau kliam greenwash disengaja atau karena pemahaman yang buruk terhadap isuisu lingkungan dan perubahan trend pasar

\section{RUMUSAN MASALAH}

1. Bagaimanakah karakteristik GMS dalam menciptakan kualitas lingkungan hidup (keberlanjutan lingkungan), profitabilitas perusahaan dan ekonomi komunitas lokal ?

2. Apakah nilia-nilai personal dalam perusahan berpengaruh terhadap kualitas lingkungan hidup (keberanjutan lingkungan), profitabilitas perusahaan dan ekonomi komunitas lokal

3. Bagaimanakah pengaruh nilai-nilai lingkungan organisasi terhadap kualitas lingkungan hidup (keberanjutan lingkungan), profitabilitas perusahaan dan pertumbuhan ekonomi komunitas lokal?

4. Bagaimanakah pengaruh peran pemerintah terhadap kualitas lingkungan hidup (keberanjutan lingkungan), profitabilitas perusahaan dan ekonomi komunitas lokal?

\section{TUJUAN PENELITIAN}

1. Untuk mengidentifikasi karakteristik perilaku yang dapat mempengaruhi pelaksanaan GMS dalam bisnis pariwisata, menemukan strategi dan sejumlah kerangka kerja untuk menjelaskan bagaimana dan mengapa perusahaan perlu mengadopsi strategi proaktif, dinamika kelembagaan, etika manajerial dan konteks organisasi dalam sebuah model bisnis pariwisata berbasis lingkungan.

2. Untuk menunjukkan bahwa hubungan antara keberlanjutan dan paradigma baru pemasaran berguna dalam 
mengembangkan produk wisata yang lebih berkelanjutan dan lebih kompetitif.

3. Untuk mengkonfirmasi bahwa asumsi daya saing adalah ilusi tanpa keberlanjutan, pengembangan tujuan pariwisata harus secara ekonomis dan ekologis serta sosial, budaya dan peran politik lingkungan yang lebih berkelanjutan lingkungan dan ekonomi yang lebih kompetitif

4. Untuk melakukan kajian literatur yang lebih mendalam membangun jembatan antara teori berkelanjutan pariwisata dan teori pemasaran baru yang lebih praktis, dan inovatif sebagai solusi bagi pengembangan pariwisata yang berbasis keberkelanjutan lingkungan.

\section{LANDASAN TEORI DAN HIPOTESIS}

\section{Kualitas Lingkungan Hidup}

Keberlanjutan ekonomi green tourism sebetulnya bukan hanya cita-cita yang tetapi keharusan ekonomi - ini masuk akal, karena ekonomi yang baik akan tumbuh dari kemampuan menjaga lingkungan - sumber daya yang memberi peluang untuk digunakan para pelaku bisnis secara kompatibel dalam memenuhi kebutuhan masa kini tanpa mengorbankan kemampuan dalam memenuhi kebutuhan generasi mendatang, konsep dasarnya dibangun berdasarkan tiga gagasan utama, pertama, mutual-simbiosis artinya keuntungan secara ekonomi dari kegiatan bisnis pariwisata sangat tergantung pada kesehatan lingkungan alam dan sosial berada dalam ikatan sistem yang terintegrasi, kedua, kebutuhan akan kepedulian masyarakat dan keterlibatannya dalam pengembangan pariwisata - mereka adalah komponen sumber daya yang terkait erat dengan pariwisata - mereka bisa merugikan lingkungan - sebaliknya, mereka bisa menjadi daya gerak kelestarian lingkungan destinasi wisata, dan ketiga, memperkuat konsep tanggungjawab pengembangan pariwisata berkelanjutan sejalan dengan kelestarian ekologi, sosial, budaya dan ekonomi (Ali Hasan, 2013).

Model green tourism marketing berorientasi aspek ekonomi, sosial dan lingkungan harus dilakukan secara terpadu untuk memenuhi semua kepentingan stakeholder, oleh karena itu bisnis harus dilakukan dengan dua cara: pertama, pengembangan dan pengelolaan kegiatan pemasaran harus dimulai dari political will pemerintah sebagai otoritas pengembangan green tourism yang didukung oleh peran serta masyarakat dalam membuka usahausaha yang berkaitan dengan kepariwisataan seperti hotel, tempat hiburan, usaha toko suvenir dan makanan, restaurant dan jasajasa yang lain. Pemerintah mempunyai kewenangan manajerial dan promosi serta masyarakat mensupportnya, kedua, paduan kerangka pemberdayaan segala potensi destinasi wisata adalah knowledge based untuk meningkatkan kesejahteraan bersama - commonwealth dengan cara (1) revitalisasi dan konservasi lingkungan resource base, (2) revitalisasi dan konservasi sejarah dan budaya - culture based, dan (3) pemberdayaan masyarakat - social based (Ali Hasan (2013),

Dalam pendekatan pemasaran utilitarian, perusahaan miskin dari tanggung jawab sosial dan menempatkan fokus yang lebih menekankan pada upaya yang memaksimalkan kekayaan pemegang saham dan pemilik (Karna, 2003). Karenannya pemasaran sering melambangkan keserakahan dan tidak bertanggung jawab terhadap dampak yang timbul dari overconsumtion dan over-development untuk keuntungan jangka pendek pribadi daripada kesejahteraan sosial dan kualitas lingkungan hidup. Organisasi menggerakkan pemasaran pariwisata tidak mengakui tragedi commons dalam menarik pariwisata massal, tidak sensitif terhadap system ekologi, akan membawa banyak dampak negatif terhadap masalah sosial dan lingkungan alam (Batra, 2006). 
Kualitas lingkungan hidup yang menurun akan mengancam kelangsungan hidup manusia dan makhluk hidup lainnya, serta pemanasan global yang semakin meningkat yang mengakibatkan perubahan iklim akan memperparah penurunan kualitas lingkungan hidup. Untuk itu perlu dilakukan perlindungan dan pengelolaan lingkungan hidup yang sungguh-sungguh dan konsisten oleh pemangku kepentingan pariwisata. Perbaikan lingkungan berpotensi membuat keuntungan baik bagi masyarakat, perusahaan dan keberlanjutan lingkungan (Ranchhod dan Gurau, 2007).

Walaupun amandemen terhadap UUD 1945 telah dilakukan, namun belum banyak perusahaan yang menempatkan praktik bisnisnya bersentuhan dengan permasalahan lingkungan hidup. Padahal hasil perubahan itu jelas membawa makna penting sekaligus harapan bagi tersedianya jaminan atas keberlangsungan lingkungan alam. misalnya Pasal 28H ayat (1) dan Pasal 33 ayat (4) UUD 1945 merupakan ketentuan kunci tentang diaturnya norma lingkungan di dalam kegiatan ekonomi. Kedua Pasal tersebut berbunyi sebagai berikut: Pasal $28 \mathrm{H}$ ayat (1) : Setiap orang berhak hidup sejahtera lahir dan batin, bertempat tinggal, dan mendapatkan lingkungan hidup yang baik dan sehat serta berhak memperoleh pelayanan kesehatan". demikian juga Pasal 33 ayat (4) : Perekonomian nasional diselenggarakan berdasar atas demokrasi ekonomi dengan prinsip kebersamaan, efisiensi berkeadilan, berkelanjutan, berwawasan lingkungan, kemandirian, serta menjaga keseimbangan kemajuan dan kesatuan ekonomi nasional".

Kedua pasal tersebut menunjukkan mandat dan otoritas bagi pemerintah untuk melakukan perlindungan baik terhadap warga negaranya untuk memperoleh lingkungan hidup yang memadai maupun jaminan terjaganya tatanan lingkungan hidup yang lestari yang terhindar dari dampak negatif sebuah aktivitas perekonomian pariwisata - perlu adanya jaminan konstitusional (constitutional guranteee) terhadap lingkungan hidup yang baik dan sehat untuk tumbuh dan berkembang bagi kehidupan manusia sekarang maupun yang akan datang.

Oleh karena itu kegiatan pemasaran pariwisata yang hanya dianggap sebagai sumber yang cepat untuk meningkatkan pertumbuhan ekonomi, fokusnya pada perluasan jumlah pengunjung secara keseluruhan ketimbang sebagai kegiatan sosial serta pandangan yang rabun terhadap peran pemasaran menjadi alasan untuk sebuah tindakan yang over-development di banyak tujuan wisata (destinations), akan mendorong pergerakan tujuan justru akan mengarah ke tahap penurunan (decline) (Batra, 2006), itu artinya bisnis pariwisata itu akan mengalami kerugian - ditinggalkan oleh pasar - wisatawan dan pada akhirnya akan bangkrut - "gulung tikar".

\section{Profitabilitas Perusahaan}

Profitabilitas merupakan serangkaian kemampuan, kebijakan dan keputusan suatu perusahaan untuk mendapatkan laba (keuntungan) dari hasil penjualan, aset, dan modal saham tertentu yang akan dijadikan sebagai dasar pembagian dividen perusahaan dalam periode tertentu. Rasio profitabilitas adalah ukuran untuk mengetahui seberapa jauh efektivitas manajemen dalam mengelola perusahaannya. Efektivitas manajemen meliputi kegiatan fungsional manajemen, seperti keuangan, pemasaran, sumberdaya manusia, dan operasional. sejalan dengan itu, rasio-rasio profitabilitas itu akan menunjukkan hasil akhir dan sejumlah kebijakan dan keputusan manajemen.

Rasio profitabilitas bertujuan untuk mengukur kemampuan perusahaan dalarn memperoleh laba, baik dalam hubungannya dengan penjualan, aset, maupun terhadap modal sendiri. Dengan demikian, rasio profitabilitas akan mengukur efektivitas 
manajemen secara keseluruhan keuntungan/ laba yang diperoleh baik dalam gross profit margin, operating profit margin, net profit margin, return on investment, return on equity, reputasi perusahaan maupun kelestarian lingkungan (Ryan and Hoontrakul, 2012).

\section{Komunitas Lokal}

Manfaat yang paling menonjol dari kebijakan dan perencanaan green tourism adalah untuk mendorong perkembangan yang memberikan manfaat bagi komunitas lokal dan lingkungan alam masyarakat setempat. Peluang pekerjaan baru, bisnis dan penghasilan tambahan, pasar baru untuk produk lokal; perbaikan infrastruktur, pelayanan masyarakat, fasilitas; keterampilan dan teknologi baru; meningkatkan kesadaran budaya dan lingkungan, konservasi dan perlindungan, dan meningkatkan penggunaan lahan. Green tourism pada tingkat masyarakat dikembangkan secara berkelanjutan dengan mengacu pada prinsip :

a. Keberlanjutan ekologis yang menjamin kompatible pembangunan ekonomi dengan proses pemeliharaan ekologi, keragaman biological dan sumber daya hayati.

b. Keberlanjutan sosial dan budaya yang menjamin peningkatan pembangunan kehidupan masyarakat setempat, kompatibel dengan budaya dan nilainilai, memelihara dan memperkuat identitas masyarakat.

c. Keberlanjutan ekonomi yang menjamin peningkatan pembangunan sumber daya ekonomi yang efisien untuk mendukung keberdayaan generasi mendatang.

Upaya melibatkan masyarakat lokal dalam bentuk memfasilitasi produk lokal, penyediaan fasilitas penjualan produk lokal, donasi untuk pengembangan budaya lokal, dan mempekerjakan masyarakat lokal sebagai staff pengelolaan destinasi untuk mempresentasikan sifat alamiah destinasi setempat, mempromosikan sebuah identitas yang unik, membuat pengalaman wisata yang menarik, mempromosikan keunggulan pariwisata, hadir melindungi alam dan manfaat bagi masyarakat lokal, mendorong sukses secara komersial dan operasi lingkungan wisata yang baru.

\section{Green Marketing Strategic}

Sesungguhnya, pemasaran menjadi alat penting untuk mempromosikan pola konsumsi yang lebih ramah lingkungan serta menjual gaya hidup baru yang berorientasi keberlanjutan lingkungan. Pemasaran itu adalah senjata api, jika digunakan tidak benar, ia akan merusak lingkungan dengan cepat, sebaliknya jika digunakan dengan cara yang benar, ia akan berkontribusi positif untuk menemukan trade-off antara kelayakan ekonomi dan keberlanjutan ekologi. Keberlanjutan ekologi harus menjadi ciri khas marketer green tourism marketing, dan mereka harus percaya dalam bekerja untuk menciptakan bisnis yang berkelanjutan dan humanis. Green marketing didefinisikan sebagai proses manajemen yang bertanggung jawab secara holistik untuk mengiden-tifikasi, mengantisipasi dan memuaskan kebutuhan pelanggan dan profitabilitas (perusahaan, masyarakat lokal dan pemerintah) tanpa merusak lingkungan alam dan tatanan hidup manusia (Mohammed and Xavier, 2010).

Orisinalitas green marketing pada keberlanjutan adalah menempatkan pemikiran holistik, dan motivasional green marketer harus mempertimbangkan seluruh rangkaian kegiatan secara holistik, seperti perencanaan, pengembangan produk baru, perubahan proses produksi, logistik, kemasan, harga, distribusi, promosi dan iklan harus ditekankan dalam proses green marketing (Chamorro \& Banegil, 2006). Oleh karena itu, green marketing tidak hanya tentang produk akhir. Sebaliknya, harus mempertimbangkan dampak dari seluruh 
siklus hidup produk, karena bagaimana suatu produk dikembangkan tidak dapat dipisahkan dari bagaimana produk itu dikonsumsi dan bagaimana produk itu mempengaruhi lingkungan. Tanpa visi green, manajemen dan marketer akan dituduh sebagai greenwashing, mengabaikan karakteristik green image dan lingkungan akan menjadi bumerang dan tidak akan mendapatkan keuntungan.

Literatur kerangka kerja GMS, menunjukkan pemodelan perilaku yang berkisar pada tingkat dan metode integrasi isu lingkungan ke dalam kegiatan perusahaan (Karna, 2003). Biasanya terinspirasi oleh ide-ide konseptual dan hierarki perencanaan pemasaran yang disajikan dalam buku teks. Penelitian GMS dalam bisnis pariwisata melibatkan keputusan tingkat strategis dan fungsional. Perusahaan perlu mempertimbangkan dampak green branding, segmentasi, penargetan dan positioning produk. Secara fungsional, peluang produk hijau harus dimasukkan ke dalam pengelolaan bauran pemasaran (Font \& Carey, 2005). Strategi pemasaran dan fungsi harus logis terkait satu sama lain. Jika fungsi lingkungan hidup yang terisolasi dari keputusan strategis asli, perusahaan tidak akan mampu menghindari sikap apatis konsumen atau ketidakpercayaan, berakhir lebih buruk daripada jika mereka tidak melakukan apa pun (Karna, 2003). Green marketing harus benar, harus berasal dari nilai-nilai lingkungan yang kuat, dan harus diinternali-sasikan dalam budaya bisnis yang lebih luas.

Pendekatan yang menerapkan kerangka kerja tanggung jawab lingkungan, untuk meningkatkan pemahaman tentang katalisasi perusahaan untuk melaksanakan GMS yang lebih proaktif. Penelitian tentang tanggung jawab terhadap lingkungan (TJL) dalam strategi pemasaran pada tingkat individu dan organisasi, kompilasi teori psikologi, sosiologi, organisasi dan etika mengeksplorasi bagaimana nilai-nilai individu dapat mempengaruhi perilaku pemasaran yang lebih bertanggung jawab terhadap lingkungan di tempat kerja, memberikan bimbingan pada jenis keahlian yang akan direkrut untuk situasi di mana TJL utama yang diinginkan (Rice. 2006). Hal ini didasarkan pada argumen bahwa aktor organisasi dapat membawa pribadi-pribadi yang berkomitment terhadap nilai-nilai kerja berbasis lingkungan, yang melampaui kepentingan ekonomi perusahaan atau pemenuhan kebutuhan pribadi.

Kajian di atas, menunjukkan bahwa karakteristik perilaku seperti pemikiran holistik, visi green image, pertimbangan green branding, segmentasi, penargetan, positioning green product dan nilainilai lingkungan personal di tempat kerja berpengaruh positif terhadap keberlanjutan lingkungan dan ekonomi. Oleh karena itu hipotesis $(\mathrm{H})$ yang akan diuji secara empiris dirumuskan sebagai berikut :

$$
\begin{aligned}
\mathrm{H}_{1}= & \text { bahwa green marketing strategic } \\
& \text { berpengaruh positif terhadap kualitas } \\
& \text { lingkungan hidup, profitabilitas } \\
& \text { perusahaan dan ekonomi komunitas } \\
& \text { lokal. } \\
\mathrm{H}_{2}= & \text { bahwa nilia-nilai personal } \\
& \text { berpengaruh positif terhadap kualitas } \\
& \text { lingkungan hidup, profitabilitas } \\
& \text { perusahaan dan ekonomi komunitas } \\
& \text { lokal }
\end{aligned}
$$

\section{Nilai-Nilai Lingkungan Organisasi}

Dalam banyak kasus, perusahaan pariwisata mengklaim bertanggung jawab bisnis terhadap lingkungan, karena mereka menyadari bahwa ini adalah hal yang benar untuk dilakukan dan berperilaku dengan cara bertanggung jawab secara sosial - dalam kasus lain karena mereka dibawah tekanan pemangku kepentingan dan owner, akibatnya manajer, marketer dan mitra internal lainnya akan jatuh dibawah kepentingan pemegang saham dan owner. Perusahaan dengan orientasi green akan 
memodifikasi seluruh budaya perusahaan untuk memastikan bahwa isu-isu lingkungan dimasukkan ke dalam setiap aspek bisnis. Ini adalah kasus yang jarang terjadi. Penelitian ini akan menunjukkan bahwa altruisme (etik) merupakan motivator penting bagi perusahaan pariwisata untuk terlibat dalam skema lingkungan (Ayuso, 2006; Rivera \& de Leon, 2005, Tzschentke, Kirk, \& Lynch, 2004).

Perusahaan pariwisata harus mengembangkan berbagai program untuk melindungi lingkungan. Misalnya, dalam rangka meningkatkan monitoring kinerja lingkungan dari sisi fasilitas, manajemen perusahaan memutuskan untuk membuat pembandingan sistem untuk semua fasilitas, melestarikan dan melindungi lingkungan alam (Bohdanowicz, 2007).

Sayangnya, sangat jarang bahkan mungkin belum ada perusahaan yang mengklaim untuk menjadi perusahaan yang ramah lingkungan yang benar-benar hijau dan memanfaatkan ide itu untuk mendapatkan pangsa pasar yang lebih besar, orientasi pada hijau hanya sebatas ikut-ikutan tanpa membuat perubahan substantif dalam tindakan lingkungan mereka. Green marketing menghadapi kegagalan untuk memenuhi janjinya sebagai alat untuk mempromosikan keberlanjutan ekologi dan sosial. Klaim green marketing yang menyesatkan - yaitu greenwashing - menyebabkan skeptisisme konsumen terhadap semua klaim, meminimalkan manfaat bagi perusahaan yang benar-benar berkomitmen untuk mempromosikan atribut produk lingkungan di pasar (Chamorro \& Banegil, 2006).

Pada tahap awal, transformasi lingkungan, keyakinan manajerial, nilai, sikap dan norma yang diharapkan menjadi penentu TJL (Rivera \& de Leon, 2005), khususnya di Indonesia di mana tekanan eksternal dan struktur regulasi belum sepenuhnya dikembangkan, dan di mana bisnis dianggap sebagai lembaga yang paling penting bagi pembangunan ekonomi. Akibatnya, para eksekutif dengan nilai ekosentrik, yang percaya bahwa perlindungan lingkungan adalah prioritas utama, mungkin mengejar agenda pelestarian atau pemeliharaan lingkungan oleh komunitas tertentu, yang mengarah ke perubahan organisasi yang diperlukan menuju budaya ramah lingkungan. Asumsi ini didukung kajian empiris dalam menghijaukan organisasi (Fryxell \& Lo, 2003; Gonzalez-Benito, 2006) terutama untuk menghasilkan literatur green tourism marketing.

Pada tingkat organisasi, kerangka kerja manajemen green tourism mengacu pada model green manajemen, adanya pelatihan staff recycling program, memiliki mitra atau menjalin kemitraan bisnis yang pro lingkungan, memiliki supplier yang memiliki komitmen greening, pemisahaan dan penendalian sampah. Pada tingkat yang sama green marketing dibedakan oleh tiga dimensi nilai-nilai organisasi, yaitu daya saing (instrumental), legitimasi (relasional) dan altruisme (etika), dan berusaha untuk memahami bagaimana dimensi nilai tersebut dapat mendorong perusahaan untuk mengimplementasikan GMS. Daya saing, berkaitan dengan lingkungan alam, menjelaskan bagaimana perusahaan dapat mencari efisiensi biaya dan peluang pasar, untuk mendapatkan kompetitif advantages atas pesaing mereka dengan menerapkan strategi proaktif lingkungan. Legitimasi berbasis nilai, namun menggunakan tindakan lingkungan sebagai sarana untuk mencapai hubungan baik dengan berbagai stakeholder secara luas dapat diterima, nilai norma dan peraturan perundangundangan yang berlaku (Marshall, Cordano, \& Silverman, 2005, Rivera, 2004). Altruisme berasal dari argumen bahwa beberapa perusahaan mengurangi dampak lingkungan karena mereka melihatnya sebagai "suatu kebenaran yang harus 
dilakukan" ( Berkhout \& Rowlands, 2007). Ini merupakan kategorisasi yang lebih luas dari nilai TJL yang konsisten dengan yang diidentifikasi dalam penghijauan organisasi (Buil-Carrasco, Fraj-Andres, \& MatuteVallejo, 2008), dimana green marketing (Baker \& Sinkula, 2005, Karna et al, 2003) dan tanggung jawab sosial perusahaan (Aguilera, Rupp, Williams, \& Ganapathi, 2007) sebagai bagian penting dalam upaya keberlanjutan lingkungan hidup yang lebih sehat dimasa-masa yang akan datang.

Literatur terakhir menunjukkan bahwa marketer yang sukses, terutama dari jaringan produk pariwisata menyadari bahwa nilai green marketing merupakan alat untuk memposisikan perusahaan di pasar, membedakan produk perusahaan dari pesaing dan untuk menciptakan hubungan yang amanah dengan stakeholder terkait, perantara pasar (misalnya tour operator), masyarakat dan yang paling penting adalah para wisatawan (Kasim, 2008). Penelitian menunjukkan bahwa selain unsur-unsur reputasi tradisional sebuah perusahaan, tanggung jawab lingkungan menjadi pusat reputasi perusahaan dan keberhasilan kompetitif di pasar saat ini (Karna, Hansen, \& Juslin, 2003), namun, untuk melihat ekspektasi green, perusahaan harus memahami pasar utamanya, dan memperlakukannya dengan cara yang baik, sebagai grail suci dari sebuah tanggung jawab sosial perusahaan. Oleh karena itu hipotesis yang akan diuji secara empiris dalam penelitian dirumuskan sebagai berikut :

$\mathrm{H}_{3}=\begin{aligned} & \text { bahwa nilai-nilai lingkungan } \\ & \text { organisasi berpengaruh positif }\end{aligned}$ terhadap kualitas lingkungan hidup manusia, profitabilitas perusahaan dan ekonomi komunitas lokal

\section{Peran Pemerintah}

Dalam pemasaran, produk apapun yang ditawarkan, endingnya tetap sama yaitu kepuasan pelanggan, keuntungan, retensi pelanggan dan keberlanjutan untuk jangka panjang. Pemasaran pariwisatapun tidak pernah lepas dari empat kepentingan itu. Oleh karena itu nilai sebuah keberlanjutan dalam pemasaran pariwisata adalah totalitas system perencanaan harga, promosi, dan produk pasar yang spesifik untuk memuaskan wisata-wan (pengalaman positif) yang memiliki manfaat sosial dan ekonomi bagi masyarakat dan keuntugan bagi perusahaan secara berkelanjutan tanpa mengorbankan sumber daya alam, Laa tufsiduu fil ardhi ba'da ish-laa hi haa - Janganlah kamu membuat kerusakan di muka bumi sesudah Tuhan-mu menciptakan dan memperbaikinya - al A'raaf : 56, 85 - haram hukumnya merusak lingkungan (Ali Hasan, 2013), ini seharusnya menjadi bagian penting yang harus di-Fatwakan oleh MUI yang di ikuti oleh undang-undang, kebijakan dan kemauan pemerintah dalam menyelamatkan lingkungan alam Indonesia. Berbagai kajian akdemis menunjukkan bahwa kontribusi potensial yang ditawarkan green tourism adalah kemampuan memaksimalkan peluang dan menghilangkan atau paling tidak meminimalkan dampak negatif terhadap lingkungan. Jika hal ini dilakukan maka basis voice green tourism economic berkembang dalam pengaturan mutualsimbiosis dengan lingkungan alam, sosial dan budaya.

Definisi dan logika ekonomi mempertegas alasan akan pentingnya penggunaan green tourism, manusia hidup di dunia memiliki sumber daya yang terbatas, dengan itu mereka harus berusaha memenuhi keinginan yang tidak terbatas. Tiga cendekiawan jagad raya di tahun 2008, Thomas Friedman, Jeffrey Sachs dan Al Gore: The Common Wealth: Economics for a Hot, Flat, and Crowded dalam Ali Hasan (2013), menyatakan bahwa bumi kita sekarang ini : Hot, bumi makin panas, karena global warming terjadi perubahan yang ekstrim dari tata iklim dunia, Flat - dunia 
ini semakin kempes - membantu berjutajuta orang dengan mudah melihat masalahmasalah global. Crowded - bumi kita ini di huni oleh 7 miliar orang. Hot dan crowded merupakan ancaman yang harus dtangani segera dan secara bersama-sama, kita yang memerlukan ketersediaan makanan yang lebih banyak, energi, dan sumber daya terbarukan - Innallaha laa yugayyiru maa biqaumin hattaa yugayyiruu maa bi an fusihiim -- Sesungguhnya Allah tidak akan merobah keadaan sesuatu kaum sebelum mereka merobah keadaan yang ada pada diri mereka sendiri - ar Ra ad 11 - we need a green revolution - ini mempertegas peran pemerintah dalam :

a. membuat kebijakan yang dapat memaksa perusahaan untuk menjadi lebih bertang-gung jawab terhadap kelestarian sumber daya lingkungan; misalnya dengan cara (1) menghentikan operasi perusahaan yang menimbulkan kerusakan lingkungan, (2) mengurangi - menghentikan produksi produk kebutuhan konsumsi yang berbahaya,

(3) meyakinkan perusahaan bahwa semua tipe konsumen memiliki kemampuan menekan perusahaan agar kegiatan mereka ramah lingkungan, menilai komposisi kebutuhan produk lingkungan dan menolak produk yang merusak lingkungan, dan (4) menunjukkan besarnya faktor biaya yang terkait dengan penanganan limbah

b. mendorong peningkatan penggunaan green tourism sebagai peluang untuk mencapai tujuan perusahaan, memperkuat moral - etika bisnis yang lebih bertanggung jawab terhadap lingkungan, budaya, sosial dan kesejahteraan masyarakat lokal.

Semua tahu bahwa, pemerintah diberi kekuasaan secara mutlak oleh negara untuk mengatur - mengelola dan menjaga keberlanjutan semua sumber daya alam untuk kepentingan - kesejahtaan masyarakat. Dukungan penuh terhadap mesin-mesin ekonomi melalui penciptaan kebijakankebijakan dan tindakan riil dala mendukung pembangunan daerah-daerah yang memiliki potensi pariwisata yang bertanggung jawab terhadap lingkungan dan keterlibatan masyarakat setempat (Lee \& Park, 2009), dan intervensi program yang didedikasikan untuk tiga bidang utama tanggung jawab yaitu kesehatan dan keselamatan lingkungan, karyawan dan wisatawan, apresiasi isu-isu sosial dan etika perusahaan dan masyarakat dalam mengurangi dampak negatif terhadap lingkungan. Oleh karena itu hipotesis yang akan diuji secara empiris dirumuskan sebagai berikut :

$\mathrm{H}_{4}=$ Bahwaperan pemerintah berpengaruh positif terhadap kualitas lingkungan hidup, profitabilitas perusahaan dan ekonomi komunitas lokal.

\section{METODE PENELITIAN}

Secara metodologis, penelitian ini termasuk dalam kategori research and development yang akan memotret pengaruh green tourism marketing terhadap keberlanjutan ekonomi dan lingkungan dari sebuah destinasi wisata dan kemudian menyimpulkan secara komparatif perbedaan karakteristik perilaku manajemen dan marketer dalam memasarkan destinasi wisata yang ada di Yogyakarta. Dari temuan penelitian ini kemudian dijabarkan dalam satu laporan penelitian dengan materi pokok identifikasi karakteristik perilaku manajer dan marketer yang terlibat secara langsung dengan green marketing strategic, nilai-nilai lingkungan personal nilai-nilai lingkungan organisasi, peran pemerintah dan paradigma ecologi baru dalam menciptakan kualitas lingkungan hidup manusia, profitabilitas perusahaan dan pertumbuhan ekonomi komunitas lokal

Sesuai dengan design penelitian diatas, maka setiap aspek risetnya adalah mencari jawaban atas pertanyaan penelitian yang dikemas dalam rumusan masalah penelitian 
dimuka. Target utama luaran penelitian ini adalah menciptakan/menghasilkan model manajemen dan pemasaran bisnis pariwisata berbasis lingkungan dan pemberdayaan masyarakat lokal

\section{Populasi dan Sampel Penelitian}

Populasi penelitian ini adalah para manajer dan manajer pemasaran yang bertanggung jawab pengelolaan dan pemasaran destinasi yang ada di Daerah Istimewa Yogyakarta. Ukuran sampel (sample size) yang akan diambil dari populasi berdasarkan ukuran minimal yang dengan nilai $€=\Pi(1-\Pi)$ adalah 0,5 (1 $-0,5)=0,25$. Nilai significance $95 \%$ dan kemungkinan kesalahan sampel (sample error) ditetapkan $10 \%$, maka nilai $\mathrm{n}$ adalah:

$$
\begin{array}{ll}
\mathrm{n}= & {\left[\mathrm{Z}^{2} \alpha / 2 \Pi(0,25)\right] / €^{2}} \\
\mathrm{n}= & {\left[\mathrm{Z}^{2} \alpha / 2\right] / 4 €^{2}} \\
\mathrm{n}= & 1,96^{2} / 4(0,10)^{2} \\
\mathrm{n}= & 96,04 \rightarrow \text { ukuran minimal }
\end{array}
$$
sampel penelitian ini adalah 96 responden

yang dipilih karena popularitas kontrak manajemen dan rantai fungsional pemasaran yang secara langsung bersentuhan dengan lingkungan dan kecepatan pengembangan respon untuk menarik wisatawan (Jameson, Ammar, Saadalla, Mostafa, \& Riegl, 2007; Shaalan, 2005). Kecuali itu sampel penelitian ini juga melibatkan 50 orang komunitas pariwisata yang secara langsung mengenal destinasi setempat.

Pendekatan terhadap sampel menggunakan "drop-off, pick-up methode", dimana peneliti mengunjungi setiap manajer pemasaran untuk menjelaskan purpose penelitian dan kemudian mengumpulkan responnya (Mostafa, 2007), metode ini cocok digunakan ketika para peneliti mengalami kesulitan dalam memperoleh sampel acak karena kurangnya frame sampling dan kurangnya keakraban manajemen dengan masalah penelitian ini. Persuasi personal diperlukan untuk mendorong respon, terutama karena sifat elit responden, kebaruan konsep green marketing dan potensi kurangnya kesadaran dan pengetahuan serta sikap negatif manajer bisnis pariwisata terhadap pentingnya penelitian akademis berkaitan dengan green tourism marketing.

\section{Variabel dan Pengukurannya}

Green Marketing Strategic (GMS), Nilai-Nilai Lingkungan Personal (NLP), Nilai-Nilai Lingkungan Organisasi (NLO) diposisikaan sebagai variabel bebas dan Peran Pemerintah (PP) sebagai variabel intervining. Sedang Kualitas Lingkungan Hidup (KLH), Orientasi Profitabilitas Perusahaan (OPP) dan Ekonomi Komunitas Lokal (EKL) diposisikan sebagai variabel terikat.

Pengukuran data digunakan skala likert yang disederhanakan menjadi 4 (empat) poin sebagai berikut :

\section{Uji Validitas dan Reliabilitas}

Dalam penelitan, reliabillitas dan validitas digunakan untuk membantu meningkatkan validitas internal dan konsistensi internal, dengan demikian dapat mengurangi ragam kesalahan pengukuran dan karenanya akan meningkatkan daya pengujian hipotesis (Souiden, Kassim, and Hong, 2006.)

\section{a. Uji Validitas}

Ukuran validitas diskriminan dihitung berdasarkan nilai ekstraksi varians bagian total (part whole) dari semua butir item konstruksi dan hasilnya sama atau lebih besar dari 0,5, (Fornell, and Larcker, 2004). logikanya, bahwa korelasi yang dibangun antar indikator akan sama atau melebihi nilai korelasi akar kuadrat pearson pada semua konstruksi. Formulasinya sebagai berikut : 


\begin{tabular}{|l|l|l|l|l|l|}
\hline \multirow{2}{*}{ Variabel } & \multicolumn{4}{|c|}{ Opsi Jawaban dan Makna } \\
\cline { 3 - 6 } & \multicolumn{1}{|c|}{4} & \multicolumn{1}{c|}{3} & \multicolumn{1}{c|}{2} & \multicolumn{1}{c|}{1} \\
\hline X1 & GMS & Sangat Relevan & Relevan & Kurang Relevan & Sangat Tidak Relevan \\
\hline X2 & NLP & Sangat Penting & Penting & Kurang Penting & Sangat Tidak Penting \\
\hline X3 & NLO & Sangat Penting & Penting & Kurang Penting & Sangat Tidak Penting \\
\hline X4 & PP & Sangat Setuju & Setuju & Kurang Setuju & Sangat Tidak Setuju \\
\hline Y1 & KLH & Sangat Penting & Penting & Kurang Penting & Sangat Tidak Penting \\
\hline Y2 & OPP & Sangat M & M & Kurang M & Sangat Tidak M \\
\hline Y3 & EKL & Sangat M & M & Kurang M & Sangat Tidak M \\
\hline \multicolumn{5}{|c|}{ M = Menguntungkan } & \\
\hline
\end{tabular}

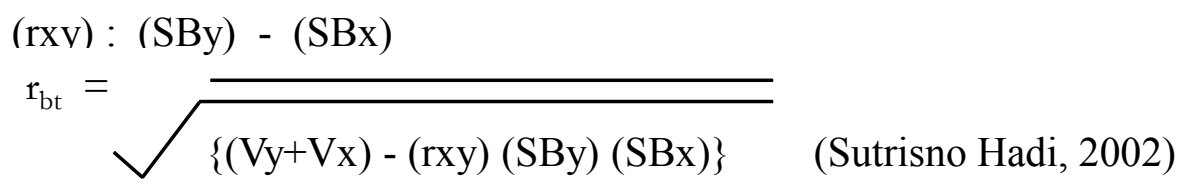

dimana :

rbt $=$ Koefisien Validitas Part Whole

rxy $=$ Koefisien Korelasi Pearson

SBy $=$ Simpangan Baku Varian Total

$\mathrm{SBx}=$ Simpangan Baku Bagian (butir)

$\mathrm{Vy}=$ Variansi Total

$\mathrm{Vx}=$ Variansi Bagian (butir)

\section{b. Uji Reliabilitas}

Ukuran reliabilitas komposit ditunjukkan oleh hasil uji keandalan

$$
\mathrm{r}_{\mathrm{tt}(\mathrm{ral})}=\frac{\mathrm{n}}{(\mathrm{n}-1)}-\left(1-\frac{\sum \mathrm{Vi}}{\mathrm{Vt}}\right)
$$

(Sutrisno Hadi, 2002)

dimana :

$$
\begin{array}{ll}
\mathrm{r}_{\mathrm{tt}(\mathrm{ral})} & =\text { Koefisien Alpha } \\
\mathrm{n} & =\text { Banyaknya jumlah butir item pertanyaan/pernyataan } \\
1 & =\text { Bilangan konstan } \\
\mathrm{V}_{\mathrm{i}} & =\text { Variansi butir item variabel } \\
\mathrm{V}_{\mathrm{t}} & =\text { Variansi total tem variable }
\end{array}
$$

nilai koefisien Cronbach's Alpha pada semua faktor konstruksi. Formulasinya sebagai berikut : 


\section{Model Analisis}

Analisis besaran kuantitatif dalam penelitian ini digunakan analisis deskriptif terhadap berbagai respon responden pada konstruksi internal variabel. Oleh karena model kenseptual-teoritis penelitian ini menunjukkan semuakonstruksi tidak terpisah satu sama lain dalam model pembentukan dampak green tourism marketing terhadap lingkungan, profitabilitas perusahaan dan ekonomi masyarakat lokal, maka analisis yang digunakan adalah model persamaan struktural (structural equation modeling) dalam bentuk diagram yang menghubungkan variabel bebas, variabel antara dan variabel terikat (gambar 1).

Pola hubungan (ditunjukkan oleh dua arah panah) variabel menunjukkan hubungan pasangan (hubungan sebabakibat) antara variabel-variabel bebas dan perantara dengan satu arah panah pada variabel terikat, menghubungkan kesalahan (variabel residue) dengan masing-masing variabel, persamaan strukturalnya sebagai berikut :

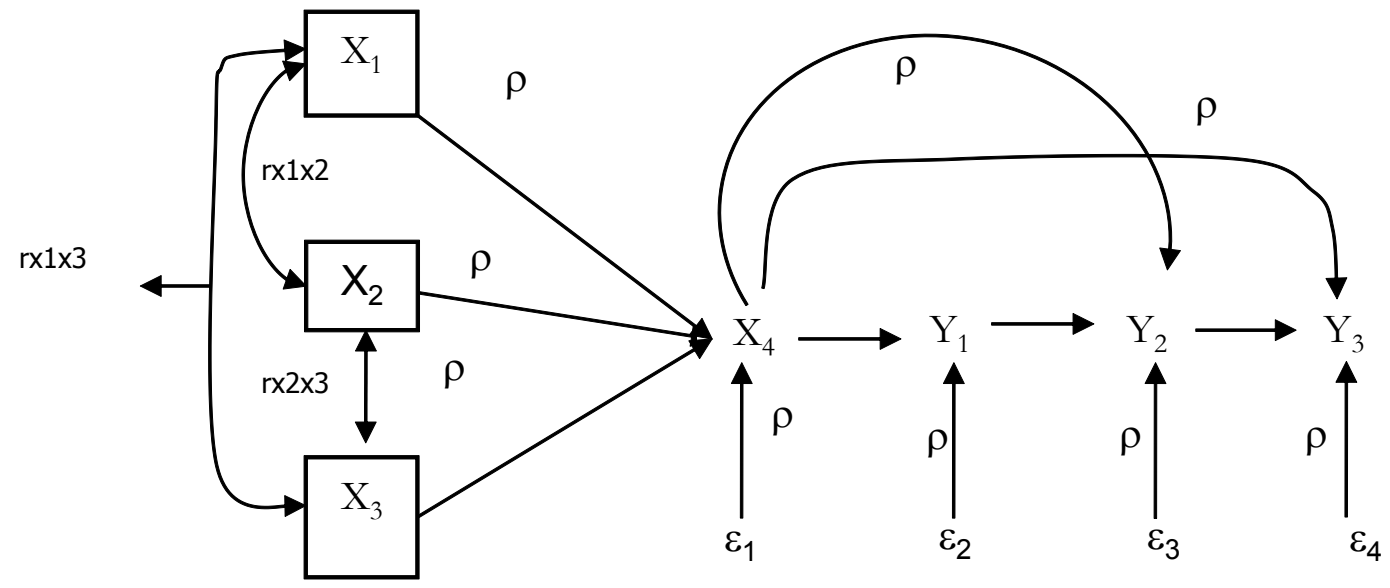

Gambar 1. Diagram Jalur Hubungan Kausal Antar Variabel

$$
\begin{aligned}
& \mathrm{X} 2=\rho_{21} \cdot X_{1}+\varepsilon \\
& \mathrm{X} 3=\rho_{31} \cdot X_{1}+\rho_{32} \cdot X_{2}+\varepsilon \\
& \mathrm{X} 4=\rho_{41} \cdot X_{1}+\rho_{42} \cdot X_{2}+\rho_{43} \cdot X_{3}+\varepsilon \\
& Y 1=\rho_{y 1} \cdot X_{1}+\rho_{\mathrm{y} 2} \cdot X_{2+} \rho_{\mathrm{y} 3} \cdot X_{3+} \varepsilon \\
& \mathrm{Y} 2=\rho_{\mathrm{y} 2} \cdot X_{2+} \rho_{\mathrm{y} 3} \cdot X_{3+} \rho_{\mathrm{y} 4} \cdot X_{4+} \varepsilon \\
& \mathrm{Y} 3=\rho_{\mathrm{y} 3} \cdot X_{3+} \rho_{\mathrm{y} 4} \cdot X_{4+} \varepsilon \quad \text { (Zaini Hasan. 1992) }
\end{aligned}
$$

dimana :

$$
\begin{array}{ll}
\mathrm{Y} 1 & =\text { Paradigma Lingkungan Manusia } \\
\mathrm{Y} 2 & =\text { Orientasi Profitabilitas Perusahaan } \\
\mathrm{Y} 3 & =\text { Pertumbuhan Ekonomi Komunitas Lokal } \\
\rho & =\text { Parameter Koefisien Jalur } \\
\rho_{\text {y1.23.4 }} & =\text { Parameter koefisien jalur } \mathrm{X}_{1.2 .3,4} \text { terhadap } \mathrm{Y}_{1}, \mathrm{Y}_{2} \text { dan } \mathrm{Y}_{3} \\
\mathrm{X}_{3} & =\text { Green Marketing Strategic } \\
\mathrm{X} 2 & =\text { Nilai-nilai lingkungan personal } \\
\mathrm{X} 3 & =\text { Nilai-nilai lingkungan Organisasi } \\
\mathrm{X} 4 & =\text { Peran Pemerintah } \\
\varepsilon & =\text { variabel gangguan / residual error }
\end{array}
$$




\section{HASIL PENELITIAN}

\section{Uji Kelayakan Instrumen}

Kuesioner penelitian ini terdiri dari 35 item pertanyaan yang secara langsung mengung-kap 7 konstruksi. Semua item konstruksi diukur dengan skala likert 5 poin, masing-masing poin akan menunjukkan power pernyataan responden. Kuesioner dibagikan kepada responden dan bersedia mengisi kuesioner (pelaku bisnis pariwisata 65 orang, karyawan dinas pariwisata 30 orang, komunitas pariwisata lokal 75 orang dan wisatawan 179) yang dibantu oleh 5 peneliti lapangan di 4 kabupaten dan 1 kota Yogyakarta. Item kuesioner disusun berdasarkan logical content validity. Uji kelayakan kuesioner digunakan Partwhole Analysis (corrected item-total correlation) dan Cronbach's Alpha Analysis, hasilnya seperti dalam tabel 1.

Tabel 1. Uji Kelayakan Kuesioner

\begin{tabular}{|c|c|c|c|c|c|}
\hline Variabel & Item & $\begin{array}{c}\text { Corrected Item-Total } \\
\text { Correlation }\end{array}$ & $\begin{array}{c}\text { Cronbach's } \\
\text { Alpha }\end{array}$ & $r$ tabel & Kesimpulan \\
\hline \multirow{5}{*}{$\begin{array}{c}\text { Green } \\
\text { Marketing } \\
\text { Strategic }\end{array}$} & 1 & ,444 & \multirow{5}{*}{, 519} & \multirow{5}{*}{,349 } & \multirow{5}{*}{$\begin{array}{l}\text { Valid dan } \\
\text { Reliabel }\end{array}$} \\
\hline & 2 & ,390 & & & \\
\hline & 3 & ,504 & & & \\
\hline & 4 & ,448 & & & \\
\hline & 5 & ,359 & & & \\
\hline \multirow{5}{*}{$\begin{array}{l}\text { Nilai-Nilai } \\
\text { Lingkungan } \\
\text { Personal }\end{array}$} & 1 & ,476 & \multirow{5}{*}{,481 } & \multirow{5}{*}{,349 } & \multirow{5}{*}{$\begin{array}{l}\text { Valid dan } \\
\text { Reliabel }\end{array}$} \\
\hline & 2 & ,374 & & & \\
\hline & 3 & ,484 & & & \\
\hline & 4 & ,379 & & & \\
\hline & 5 &, 474 & & & \\
\hline \multirow{5}{*}{$\begin{array}{l}\text { Nilai-Nilai } \\
\text { Lingkungan } \\
\text { Organisasi }\end{array}$} & 1 &, 365 & \multirow{5}{*}{,624 } & \multirow{5}{*}{,349 } & \multirow{5}{*}{$\begin{array}{l}\text { Valid dan } \\
\text { Reliabel }\end{array}$} \\
\hline & 2 & , 459 & & & \\
\hline & 3 & ,506 & & & \\
\hline & 4 & ,462 & & & \\
\hline & 5 & ,521 & & & \\
\hline \multirow{5}{*}{$\begin{array}{c}\text { Peran } \\
\text { Pemerintah }\end{array}$} & 1 & ,641 & \multirow{5}{*}{,492 } & \multirow{5}{*}{,349 } & \multirow{5}{*}{$\begin{array}{l}\text { Valid dan } \\
\text { Reliabel }\end{array}$} \\
\hline & 2 & ,577 & & & \\
\hline & 3 & ,487 & & & \\
\hline & 4 & ,659 & & & \\
\hline & 5 & ,477 & & & \\
\hline \multirow{5}{*}{$\begin{array}{c}\text { Kualitas } \\
\text { Lingkungan } \\
\text { Hidup }\end{array}$} & 1 & ,367 & \multirow{5}{*}{,372 } & \multirow{5}{*}{,349 } & \multirow{5}{*}{$\begin{array}{l}\text { Valid dan } \\
\text { Reliabel }\end{array}$} \\
\hline & 2 & ,528 & & & \\
\hline & 3 & ,436 & & & \\
\hline & 4 & , 460 & & & \\
\hline & 5 & ,469 & & & \\
\hline \multirow{5}{*}{$\begin{array}{l}\text { Profitabilitas } \\
\text { Perusahaan }\end{array}$} & 1 & ,707 & \multirow{5}{*}{,855 } & \multirow{5}{*}{,349 } & \multirow{5}{*}{$\begin{array}{l}\text { Valid dan } \\
\text { Reliabel }\end{array}$} \\
\hline & 2 &, 695 & & & \\
\hline & 3 & , 455 & & & \\
\hline & 4 & ,796 & & & \\
\hline & 5 & ,698 & & & \\
\hline
\end{tabular}




\begin{tabular}{|c|c|c|c|c|c|}
\hline Variabel & Item & $\begin{array}{c}\text { Corrected Item-Total } \\
\text { Correlation }\end{array}$ & $\begin{array}{c}\text { Cronbach's } \\
\text { Alpha }\end{array}$ & $r$ tabel & Kesimpulan \\
\hline Ekonomi & 1 &, 611 & & & \\
Komunitas & 3 &, 371 &, 632 &, 349 & Valid dan \\
Lokal & 4 &, 409 & & & Reliabel \\
& 5 &, 335 & & & \\
\hline
\end{tabular}

dari tabel 1 terlihat bahwa masingmasing item dalam semua konstruksi baik nilai koefisien partwhole maupun cronbach's alpha lebih tinggi dari nilai tabel $r$, oleh karena itu semua item dinyatakan valid dan semua konstruksi dinyatakan reliabel. Dengan demikian intrumen ini layak digunakan mengumpulkan data penelitian untuk tujuan pengujian hipotesis termasuk untuk menjelaskan temuan penelitian ini.

\section{Uji Normalitas}

Berdasarkan hasil uji normalitas pada tiga variabel terikat seperti dalam tabel 2 dibawah ini, terlihat semua nilai koefisien $\chi^{2}$ lebih besar dari $\alpha 0.05$, dengan demikian ketiga variabel terikat ini sebarannya mengikuti distribusi normal (Sutrisno Hadi, 2002).

Tabel 2. Hasil Uji Normalitas

\begin{tabular}{|l|c|c|c|}
\hline \multirow{4}{*}{ Model } & \multicolumn{3}{|c|}{ Variabel Terikat } \\
\cline { 2 - 4 } & $\begin{array}{c}\text { Kualitas } \\
\text { Lingkungan } \\
\text { Hidup }\end{array}$ & $\begin{array}{c}\text { Orientasi } \\
\text { Profitabilitas } \\
\text { Perusahaan }\end{array}$ & $\begin{array}{c}\text { Ekonomi } \\
\text { Komunitas } \\
\text { Lokal }\end{array}$ \\
\hline Chi-Square & 201,831 & 129,874 & 177,074 \\
\hline Df & 15 & 16 & 15 \\
\hline Asymp. Sig &, 000 &, 000 &, 000 \\
\hline
\end{tabular}

\section{Uji Linieritas}

Hasil analisis linieritas variabel Green Marketing Strategic, Nilai-Nilai Lingkungan Personal, Nilai-Nilai Lingkungan Organisasi dan Peran Pemerintah terhadap total variabel terikat (Kinerja Bisnis: Kualitas Lingkungan, Profitabilitas, Ekonomi Komunitas Lokal) seperti dalam tabel 3 dibawah ini, terlihat semua nilai $\boldsymbol{F}$ lebih besar dari $\alpha 0.05$, oleh karena itu korelasi semua variabel bebas dengan variabel terikat mengikuti garis linier (Vincent Gaspersz, 1991).

\section{Uji Multikolinearitas}

Untuk menditeksi nilai multikolinearitas digunakan koefisien VIF (Variance Inflation Factor - yang didefinisikan sebagai ukuran variable-variabel yang berkontribusi terhadap standard error dalam regresi). Multikolinieritas terjadi jika nilai koefisien VIF lebih dari 5 (>5) dan nilai tolerance lebih dari $1(>1)$, maka derajad multikolinearitas semakin tinggi (Liao and Valliant, 2012). Berdasarkan hasil analisis multikolinieritas seperti dalam tabel 4.4 dibawah ini, terlihat nilai VIF dalam semua konstruksi berada di 
Tabel 3. Hasil Analisis Linieritas

\begin{tabular}{|c|c|c|c|c|c|}
\hline \multirow{3}{*}{ Variabel Bebas } & \multicolumn{5}{|c|}{ Koefisien ${ }^{a}$} \\
\hline & \multicolumn{2}{|c|}{$\begin{array}{l}\text { Unstandardized } \\
\text { Coefficients }\end{array}$} & \multirow{2}{*}{$\begin{array}{c}\begin{array}{c}\text { Standardized } \\
\text { Coefficients }\end{array} \\
\text { Beta }\end{array}$} & \multirow[t]{2}{*}{$\mathbf{t}$} & \multirow[t]{2}{*}{ Sig. } \\
\hline & B & Std. Error & & & \\
\hline $\begin{array}{l}\text { Green Marketing } \\
\text { Strategic }\end{array}$ & , 104 &, 037 & ,322 & 2,098 &, 004 \\
\hline $\begin{array}{l}\text { Nilai-Nilai } \\
\text { Lingkungan Personal }\end{array}$ & , 195 & ,044 &, 350 & 4,409 &, 000 \\
\hline $\begin{array}{l}\text { Nilai-Nilai } \\
\text { Lingkungan } \\
\text { Organisasi }\end{array}$ & ,113 &, 047 & ,387 & 3,271 & ,003 \\
\hline Peran Pemerintah & ,203 & ,044 & ,283 & 4,647 &, 000 \\
\hline
\end{tabular}

bawah 10 dan nilai toleransiberada dibawah multikolinier antar variabel bebas. angka 1, dengan demikian tidak terjadi

Tabel 4. Hasil Analisis Multikolinieritas

\begin{tabular}{|l|c|c|}
\hline \multirow{2}{*}{\multicolumn{1}{|c|}{ Model }} & \multicolumn{2}{c|}{ Coefficients Collinearity Statistics ${ }^{a}$} \\
\cline { 2 - 3 } & Tolerance & VIF \\
\cline { 2 - 3 } &, 523 & 1,912 \\
\hline Green Marketing Strategic &, 303 & 3,296 \\
\hline Nilai-Nilai Lingkungan Personal &, 266 & 3,753 \\
\hline Nilai-Nilai Lingkungan Organisasi &, 513 & 1,950 \\
\hline Peran Pemerintah & \multicolumn{2}{|c|}{} \\
\hline \multirow{2}{*}{${ }^{*}$. Variabel Terikat: Kinerja Bisnis (Kualitas Lingkungan, Profitabilitas, Ekonomi Komunitas Lokal) } \\
\hline
\end{tabular}

\section{Uji Autokorelasi}

Uji autokorelasi ini digunakan untuk memastikan bahwa dalam model regresi jalur tidak ada korelasi antar error satu dengan error yang lainnya. Gejala autokorelasi dideteksi dengan uji Durbin Watson (DW) pada output model summary. Hasil analisis Durbin-Watson menunjukkan bahwa $d_{L}>d_{o}$ $<d_{u}, 1,728>1,203<1,810$, dengan demikian tidak ada autokorelasi dalam model regresi jalur.

Dengan terpenuhinya uji normalitas, uji linieritas, bebas dari gejala multikolinieritas, dan gejala autokorelasi. maka Structural Equation Modeling adalah model yang tepat digunakan untuk menganalisis data penelitian ini. 
6. Hasil Analisis Structural Equation Modeling

Dalam penelitian ini, nilai koefisien structural equation modeling digunakan sebagai parameter uji keterikatan berbagai variabel bebas dengan variabel terikat. Dalam tabel 4.5 terlihat sepuluh kasus menunjukan pengaruh yang sangat kuat ( $p$
$<0,01)$, sementara dua lainnya menunjukan pengaruh yang kuat $\left(\mathrm{p}<0,05-\mathrm{H}_{\mathrm{x} 3 \mathrm{y} 1}\right.$ dan $\mathrm{H}_{x 4-\mathrm{y} 1}$ ). Kecuali itu, temuan penelitian yang diringkas dalam gambar 4.1, bahwa pada taraf signifikansi $\left(^{* *}\right) \quad 1 \%$ atau $\mathrm{p}<0,01$ menunjukkan pola dan kekuatan hubungan kausalitas antar variabel dengan diterminasi efektif (R Square) yang berbeda. Secara lebih rinci dapat dijelaskan sebagai berikut :

Tabel 5 Koefisien Structural Equation Modeling

\begin{tabular}{|c|c|c|c|c|c|c|c|}
\hline & Komposit & $\begin{array}{l}\text { Variabel } \\
\text { Terikat }\end{array}$ & Hipotesis & $\boldsymbol{\beta}$ & Signif. & $\begin{array}{l}\text { Kesim } \\
\text { pulan }\end{array}$ & $\mathbf{R}-\mathbf{S q}$ \\
\hline 1 & $\begin{array}{l}\text { Green } \\
\text { Marketing } \\
\text { Strategic }\end{array}$ & Y1 & $\mathrm{H}_{\mathrm{x} 1-\mathrm{y} 1}$ & ,274 &, 000 & diterima & $31.70 \%$ \\
\hline 2 & $\begin{array}{l}\text { Nilai-Nilai } \\
\text { Lingkungan } \\
\text { Personal }\end{array}$ & Y1 & $\mathrm{H}_{\mathrm{x} 2-\mathrm{y} 1}$ & , 191 &, 001 & diterima & $29,4 \%$ \\
\hline 3 & $\begin{array}{l}\text { Nilai-Nilai } \\
\text { Lingkungan } \\
\text { Organisasi }\end{array}$ & Y1 & $\mathrm{H}_{\mathrm{x} 3-\mathrm{y} 1}$ & , 178 & ,020 & diterima & $21,3 \%$ \\
\hline 4 & $\begin{array}{l}\text { Peran } \\
\text { Pemerintah }\end{array}$ & Y1 & $\mathrm{H}_{\mathrm{x} 4-\mathrm{y} 1}$ & , 109 &, 033 & diterima & $17,9 \%$ \\
\hline 1 & \begin{tabular}{|l} 
Green \\
Marketing \\
Strategic
\end{tabular} & Y2 & $\mathrm{H}_{\mathrm{x} 1-\mathrm{y} 2}$ & ,454 &, 000 & diterima & $46.80 \%$ \\
\hline 2 & $\begin{array}{l}\text { Nilai-Nilai } \\
\text { Lingkungan } \\
\text { Personal }\end{array}$ & Y2 & $\mathrm{H}_{\mathrm{x} 2-\mathrm{y} 2}$ & ,456 &, 000 & diterima & $42,0 \%$ \\
\hline 3 & $\begin{array}{l}\text { Nilai-Nilai } \\
\text { Lingkungan } \\
\text { Organisasi }\end{array}$ & Y2 & $\mathrm{H}_{\mathrm{x} 3-\mathrm{y} 2}$ & ,425 &, 000 & diterima & $36,0 \%$ \\
\hline 4 & $\begin{array}{l}\text { Peran } \\
\text { Pemerintah }\end{array}$ & Y2 & $\mathrm{H}_{\mathrm{x} 4-\mathrm{y} 2}$ & ,426 & ,000 & diterima & $37,9 \%$ \\
\hline 1 & $\begin{array}{l}\text { Green } \\
\text { Marketing } \\
\text { Strategic }\end{array}$ & Y3 & $\mathrm{H}_{\mathrm{x} 1-\mathrm{y} 3}$ & ,209 &, 000 & diterima & $24.80 \%$ \\
\hline 2 & $\begin{array}{l}\text { Nilai-Nilai } \\
\text { Lingkungan } \\
\text { Personal }\end{array}$ & Y3 & $\mathrm{H}_{\mathrm{x} 2-\mathrm{y} 3}$ & ,308 &, 000 & diterima & $40,4 \%$ \\
\hline 3 & $\begin{array}{l}\text { Nilai-Nilai } \\
\text { Lingkungan } \\
\text { Organisasi }\end{array}$ & Y3 & $\mathrm{H}_{\mathrm{x} 3-\mathrm{y} 3}$ & ,332 & ,000 & diterima & $44,0 \%$ \\
\hline 4 & $\begin{array}{l}\text { Peran } \\
\text { Pemerintah }\end{array}$ & Y3 & $\mathrm{H}_{\mathrm{x} 4-\mathrm{y} 3}$ &, 544 & ,000 & diterima & $55,7 \%$ \\
\hline & Konstanta & $\mathrm{Yt}$ & $\mathrm{H}_{\mathrm{yt}}$ & 9,866 & ,000 & diterima & $58,6 \%$ \\
\hline
\end{tabular}




\section{Kelompok Pertama :}

1. Hasil analisis $\mathrm{H}_{\mathrm{xl}-\mathrm{y} 1}$ menunjukkan bahwa koefisien $\beta=0,274, \mathrm{p}=0.000$ artinya bahwa green marketing strategic berpengaruh signifikan terhadap kualitas lingkungan hidup (keberanjutan lingkungan). Besarnya diterminasi efektif green marketing strategic adalah $31.1 \%$. Hasil ini membenarkan bahwa variabel green marketing strategic dapat membantu kampanye peningkatan kualitas lingkungan hidup.

2. Hasil analisis $\mathrm{H}_{\mathrm{x} 2-\mathrm{y} 1}$ menunjukkan bahwa koefisien $\beta=0.191, \mathrm{p}=$ 0.001 artinya bahwa nilai-nilai lingkungan personal berpengaruh signifikan terhadap kualitas lingkungan hidup (keberanjutan lingkungan). Besarnya diterminasi efektif nilai-nilai lingkungan personal adalah 29,4\%. Hasil ini membenarkan bahwa nilainilai lingkungan personal dapat meningkatkan kualitas lingkungan hidup.

3. Hasil analisis $\mathrm{H}_{\mathrm{x} 3-\mathrm{y} 1}$ menunjukkan bahwa koefisien $\beta=0.178, \mathrm{p}=$ 0.020 artinya bahwa nilai-nilai lingkungan organisasi berpengaruh signifikan terhadap kualitas lingkungan hidup (keberanjutan lingkungan). Besarnya diterminasi efektif nilai-nilai lingkungan organisasi adalah 21,3\%, Hasil ini membenarkan bahwa nilainilai lingkungan organisasi dapat meningkatkan kualitas lingkungan hidup.

4. Hasil analisis $\mathrm{H}_{\mathrm{x} 4 \mathrm{-y} 1}$ menunjukkan bahwa koefisien $\beta=0.109, p$ $=0.033$ artinya bahwa peran pemerintah berpengaruh signifikan terhadap kualitas lingkungan hidup (keberanjutan lingkungan). Besarnya diterminasi efektif peran pemerintah adalah $17.9 \%$. Hasil ini membenarkan bahwa peran pemerintah dapat meningkatkan kualitas lingkungan hidup.

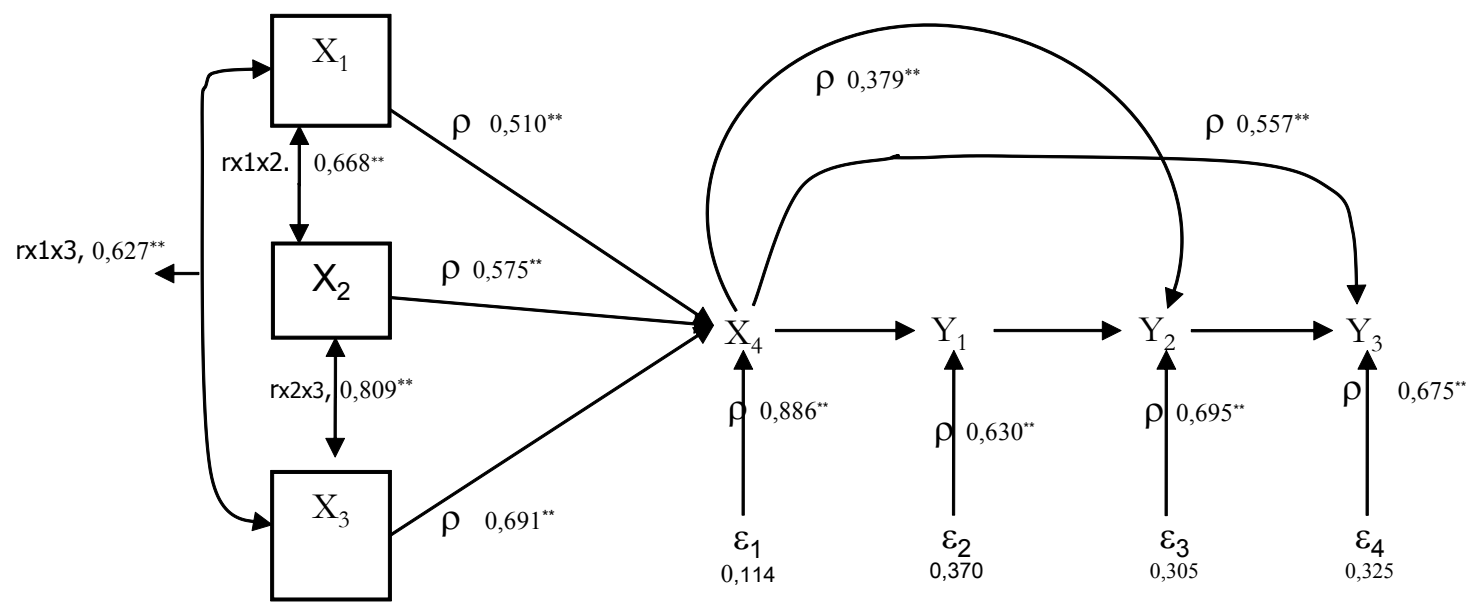

Gambar 2. Ringkasan Temuan Hubungan Kausal Antar Variabel

Keterangan : ** signifikan pada level 0.01 


\section{Kelompok Kedua :}

5. Hasil analisis $\mathrm{H}_{\mathrm{x} 1 \mathrm{-y} 2}$ menunjukkan bahwa koefisien $\beta=0,454, \mathrm{p}=0.000$ artinya bahwa green marketing strategic berpengaruh signifikan terhadap profitabilitas perusahaan. Besarnya diterminasi efektif green marketing strategic adalah $46.8 \%$. Hasil ini membenarkan bahwa variabel green marketing strategic dapat membantu meningkatkan profitabilitas perusahaan.

6. Hasil analisis $\mathrm{H}_{\mathrm{x} 2-\mathrm{y} 2}$ menunjukkan bahwa koefisien $\beta=0.456, \mathrm{p}=$ 0.000 artinya bahwa nilai-nilai lingkungan personal berpengaruh signifikan terhadap profitabilitas perusahaan. Besarnya diterminasi efektif nilai-nilai lingkungan personal adalah 42\%. Hasil ini membenarkan bahwa nilainilai lingkungan personal dapat meningkatkan profitabilitas perusahaan.

7. Hasil analisis $\mathrm{H}_{\mathrm{x} 3-\mathrm{y} 2}$ menunjukkan bahwa koefisien $\beta=0.425, \mathrm{p}=$ 0.000 artinya bahwa nilai-nilai lingkungan organisasi berpengaruh signifikan terhadap profitabilitas perusahaan. Besarnya diterminasi efektif nilai-nilai lingkungan organisasi adalah 36\%, Hasil ini membenarkan bahwa nilainilai lingkungan organisasi dapat meningkatkan profitabilitas perusahaan.

8. Hasil analisis $\mathrm{H}_{x 4-\mathrm{y} 2}$ menunjukkan bahwa koefisien $\beta=0.426$, p $=0.000$ artinya bahwa peran pemerintah berpengaruh signifikan terhadap profitabilitas perusahaan. Besarnya diterminasi efektif peran pemerintah adalah 37.9\%. Hasil ini membenarkan bahwa peran pemerintah dapat meningkatkan profitabilitas perusahaan.

\section{Kelompok Ketiga :}

9. Hasil analisis $\mathrm{H}_{\mathrm{xl-y3}}$ menunjukkan bahwa koefisien $\beta=0,209, \mathrm{p}=0.000$ artinya bahwa green marketing strategic berpengaruh signifikan terhadap pertumbuhan ekonomi komunitas pariwisata lokal. Besarnya diterminasi efektif green marketing strategic adalah $24.8 \%$. Hasil ini membenarkan bahwa variabel green marketing strategic dapat membantu meningkatkan pertumbuhan ekonomi komunitas pariwisata lokal.

10. Hasil analisis $\mathrm{H}_{\mathrm{x} 2-\mathrm{yz}}$ menunjukkan bahwa koefisien $\beta=0.308, \mathrm{p}=$ 0.000 artinya bahwa nilai-nilai lingkungan personal berpengaruh signifikan pertumbuhan ekonomi komunitas pariwisata lokal. Besarnya diterminasi efektif nilainilai lingkungan personal adalah 40,4\%. Hasil ini membenarkan bahwa nilai-nilai lingkungan personal dapat meningkatkan pertumbuhan ekonomi komunitas pariwisata lokal.

11. Hasil analisis $\mathrm{H}_{\mathrm{x} 3 \mathrm{-y} 3}$ menunjukkan bahwa koefisien $\beta=0.332, \mathrm{p}=$ 0.000 artinya bahwa nilai-nilai lingkungan organisasi berpengaruh signifikan terhadap pertumbuhan ekonomi komunitas pariwisata lokal. Besarnya diterminasi efektif nilai-nilai lingkungan organisasi adalah 44\%, Hasil ini membenarkan bahwa nilai-nilai lingkungan organisasi dapat meningkatkan pertumbuhan ekonomi komunitas pariwisata lokal.

12. Hasil analisis $\mathrm{H}_{\mathrm{x} 4 \mathrm{-y3}}$ menunjukkan bahwa koefisien $\beta=0.544, \mathrm{p}$ $=0.000$ artinya bahwa peran pemerintah berpengaruh signifikan terhadap pertumbuhan ekonomi komunitas pariwisata lokal. 
Besarnya diterminasi efektif peran pemerintah adalah $55.7 \%$. Hasil ini membenarkan bahwa peran pemerintah dapat meningkatkan pertumbuhan ekonomi komunitas pariwisata lokal.

13. Hasil analisis $\mathrm{H}_{\mathrm{x} 1,2,3,4-\mathrm{yt}}$ menunjukkan bahwa koefisien $\beta=9,866 \mathrm{p}=0.000$ artinya bahwa green marketing strategic, nilai-nilai lingkungan personal, nilai-nilai lingkungan organisasi dan peran pemerintah secara simultan berpengaruh signifikan terhadap kualitas lingkungan hidup (keberlanjutan lingkungan), profitabilitas perusahaan dan pertumbuhan ekonomi komunitas pariwisata lokal. Besarnya diterminasi efektif green marketing strategic, nilainilai lingkungan personal, nilainilai lingkungan organisasi dan peran pemerintah adalah 58.6\%. Hasil ini membenarkan bahwa green marketing strategic, nilainilai lingkungan personal, nilainilai lingkungan organisasi dan peran pemerintah dapat meningkatkan kualitas lingkungan hidup, profitabilitas perusahaan dan pertumbuhan ekonomi komunitas pariwisata lokal.

\section{PEMBAHASAN}

Riset ini menyoroti dampak green marketing strategic, nilai-nilai lingkungan personal, nilai-nilai lingkungan organisasi dan peran pemerintah terhadap kualitas lingkungan hidup, profitabilitas perusahaan dan pertumbuhan ekonomi komunitas pariwisata lokal. Keberhasilan jangka panjang (berkelanjutan) dari setiap bangsa, bisnis dan pertumbuhan ekonomi masyarakat local tidak terkecuali dalam pariwisata tergantung pada kemampuan dan kemauan untuk memelihara, memperbaiki dan meningkatkan kualitas lingkungan hidup, oleh karena itu konservasi lingkungan dan sumberdaya alam memerlukan kepaduan dan keterlibatan aktif dari tiga komponen utama yaitu pemerintah, praktisi dan asosiasi bisnis pariwisata serta komunitas pariwisata local untuk mensinergikan perannya dalam membangun pariwisata berbasis lingkungan.

Secara akademik, hasil penelitian ini menunjukkan integrasi konstruksi dalam model pariwisata berbasis lingkungan akan mampu memperluas konsep ekonomi pariwisata baik bagi pemerintah, pebisnis dan masyarakat local dalam hubungan kontinjensional yang memiliki fokus pada efek utama dan efek antara dari faktor konstruksi sebagai anteseden kualitas lingkungan hidup dan sumberdaya alam. Kegagalan menggabungkan hubungan itu akan menyebabkan lemahnya proses retensi keberadaan bangsa, dan kelangsungan hidup bisnis dan masyarakat akan terancam

Dalam hal praktek, hasil riset ini mendukung pentingnya membangun katalisasi peran pemerintah, pebisnis dan komunitas pariwisata lokal sebagai talkers dalam membangun keterikatan hubungan manusia dengan kelanjutan sumberdaya lingkungannya. Mentalitas industriawan pariwisata ke depan harus didominasi oleh paradigma "new technovironment centric" yang memberikan penekanan pada kemampuan teknologi yang ramah lingkungan sebagai dasar keputusan dalam melihat lingkungan sebagai sesuatu yang hadir untuk mendukung potensi sosialekonomi yang dominan dalam kaitannya dengan lingkungan melalui sebuah pendekatan zero waste, zero-discharge. Mencegah limbah, memulihkan dan menggunakan kembali untuk mengurangi biaya adalah tujuan penting dari pengelolaan bisnis. Oleh karena itu pemerintah harus memastikan bahwa konsep green marketing, nilai personal, nilai organisasional (temasuk bisnis) dibangun berdasarkan prinsip :

1. Menjadikan ekosistem sebagai faktor 
pembatas fisik dalam pemasaran, bisnis dan ekonomi masyarakat;

2. Menjadikan sistem siklus hidup produk sebagai kerangka keputusan yang tepat dalam pemasaran, bisnis dan ekonomi masyarakat;

3. Melakukan pencegahan polusi dan pemulihan sumber daya sebagai strategi yang tepat untuk mencapai keberlanjutan

4. Kesadaran multiplier effect akan ada sekalipun kecil (yaitu, penghematan biaya) jika perbaikan lingkungan dilakukan oleh perusahaan, pelanggan dan masyarakat di tingkat mikro diterjemahkan ke dalam perbaikan besar di tingkat makro-pemerintah

5. Pemasaran berkelanjutan bukan merupakan latihan tetapi harus menjadi budaya korporat dan kegiatan masyarakat.

6. Paradigma green marketing harus sejalan dengan paradigma lingkungan dengan mengambil langkah-langkah untuk meningkatkan kualitas lingkungan dan menghindari resiko skimming off .

Sebuah solusi untuk problem lingkungan adalah kampanye yang terus menerus untuk meningkatkan kesadaran lingkungan. Ketergantungan pada perubahan setiap indikator dalam konstruksi akan menjadi penentu kualitas lingkungan hidup, oleh karena itu pemerintah, pebisnis dan komunitas lokal sebagai penyedia jasa wisata harus mengikat wisatawan dalam kontek kelanjutan kualitas lingkungan dalam jangka panjang, diagnosis kualitas, nilai personal dan organisasi (bisnis) merupakan keputusan penting dalam meningkatkan kualitas lingkungan, keuntungan bagi perusahaan dan komunitas pariwisata. Selain itu mengidentifikasi kekuatan merupakan apaya untuk meningkatkan kualitas hidup keuntungan bagi perusahaan dan komunitas pariwisata. Demikian juga identifikasi kelemahan komponen kualitas, nilai relatif dam perilaku perusahaan dapat digunakan untuk mengatasi kelemahan kritis yang umumnya menghambat upaya meningkatkan kualitas lingkungan hidup keuntungan bagi perusahaan dan komunitas pariwisata.

Hasil uji hipotesis penelitian ini sangat berharga bagi pemerintah, pebisnis dan komunitas pariwisata lokal baik dalam rangka mempromosikan destinasi pariwisata maupun untuk menciptakan multiplier effect dalam memenuhi tuntutan ekonomi.

\section{KESIMPULAN}

Berdasarkan hasil analisis dan pembahasan di muka, maka kesimpulan penelitian dapat dirumuskan sebagai berikut

1. Green Marketing Strategic berpengaruh signifikan dan dapat meningkatkan kualitas lingkungan hidup, profitabilitas perusahaan dan pertumbuhan ekonomi komunitas lokal.

2. Nilai-nilai personal dalam perusahan berpengruh signifikan dan dapat meningkatkan kualitas lingkungan hidup, profitabilitas perusahaan dan pertumbuhan ekonomi komunitas local.

3. Nilai-nilai lingkungan organisasi berpengaruh signifikan dan dapat meningkatkan kualitas lingkungan hidup manusia, profitabilitas perusahaan dan pertumbuhan ekonomi komunitas local.

4. Peran pemerintah berpengaruh signifikan dan dapat meningkatkan kualitas lingkungan hidup, profitabilitas perusahaan dan pertumbuhan ekonomi komunitas local.

\section{DAFTAR PUSTAKA}

Aguilera, R.V., Rupp, D.E., Williams, C.A., \& Ganapathi, J. 2007. Putting the back in corporate social responsibility: A multilevel theory of social change in organizations. The Academy 
of Management Review, 32(3), 836-863.

Ali Hasan, 2013. Green Tourism : Alternatif Jitu Dalam Menyelamatkan Lingkungan, Sosial, Dan Budaya. Orasi Ilmiah Dalam Dies Natalis Sekolah Tinggi Pariwisata Yogyakarta ke 26, 13 Januari 2013. STP AMPTA Yogyakarta.

Ayuso, S. 2006. Adoption of voluntary environmental tools for sustainable tourism: Analysing the experience of hotels. Corporate Social Responsibility and Environmental Management, 13(4), 207-720.

Baker, W.E., \& Sinkula, J.M. 2005. Environmental marketing strategy and firm performance: Effects on new product performance and market share. Journal of the Academy of MarketingScience, 33(4), 461475.

Batra, A. 2006. Tourism marketing for sustainable development. ABAC Journal, 26(1), 59-65.

Bohdanowicz, P. 2007. A Environmental Reporting as a tool of corporate social responsibility. Tourism Review International, 11(2), 115-131.

Buil-Carrasco, I., Fraj-Andres, E., \& MatuteVallejo, J. 2008. Corporate environmentalism strategy in consumer product sector: A typology of firms. Business Strategy and the Environment, 17(6), 350-368.

Chamorro, A., \& Ba negil, T.M. 2006. Green marketing philosophy: A firms with ecolabels. Corporate
Social Responsibility and Environmental Management, 13(1), 11-24.

Clark, C.F., Kotchen, M.J., \& Moore, M.R. 2003. Internal and external influences on proenvironmental behavior: Participation in a green electricity program. Journal of Environmental Psychology, 23(3), 237-246.

Font, X., \& Carey, B. 2005. Marketing sustainable tourism products. Florence, Italy: Regione Toscana and United Nations Environment Programme.

Fryxell, G.E.,\&Lo, C.W. 2003. The influence of environmental knowledge and values on managerial behaviours on behalf of the environment: An empirical examination of managers in China. Journal of Business Ethics, 46(1), 45-69.

Fornell, C., and Larcker, D. F. 2004. Evaluating Structural Equation Models With Unobservable Variables and Measurement Error. Journal of Marketing Research, 18, 39-80.

Gonz'alez-Benito, J. 2006. The role of stakeholder pressure and managerial values in the implementation of environmental logistics practices.International Journal of Production Research, 44, 1353-1373.

Jameson, S.C., Ammar, M.S.A., Saadalla, E., Mostafa, H.M., \& Riegl, B. 2007. A quantitative ecological assessment of diving sites in the Egyptian Red Sea during a period of severe anchor damage: A baseline 
for restoration and sustainable tourism management. Journal of Sustainable Tourism, 15, 309-323.

Karna, J., Hansen, E., \& Juslin, H. 2003. Social responsibility in environmental marketing planning. European Journal of Marketing, 37(5/6), 848-871.

Kasim, A. 2008. Socially responsible hospitality and tourism marketing. Handbook of hospitality marketing Boston, MA: Butterworth-Heinemann. pp. 32-58.

2007. Corporate environmentalism in the hotel sector: Evidence of drivers and barriers in Penang, Malaysia. Journal of Sustainable Tourism, 15(6), 680-699.

2006. The need for business environmental and social responsibility in the tourism industry. International Journal of Hospitality and Tourism Administration, 7(1), 1-22.

Lee, S., \& Park, S.-Y. 2009. Do socially responsible activities help hotels and casinos achieve their financial goals? International Journal of Hospitality Management, 28, 105-112.

Liao, D and Valliant, R. 2012. Variance inflation factors in the analysis of complex survey data. Survey Methodology, Vol. 38, No. 1, pp. 53-62

Marshall, R.S., Cordano, M., \& Silverman, M. 2005. Exploring individual and institutional drivers of proactive environmentalism in the U.S. wine industry. Business Strategy and the
Environment, 14(2), 92-109.

Marta, J.K., Singhapakdi, A., Attia, A., \& Vitell, S.J. 2004. Some important factors underlying ethical decisions of Middle-Eastern marketers. International Marketing Review, 21(1), 53-67.

Mostafa, M.M. 2007. A hierarchical analysis of the green consciousness of the consumer. Psychology and Marketing, 24(5), 445-473.

Mohammed El Dief and Xavier Font, 2010. The determinants of managers' green marketing behaviour. Journal of Sustainable Tourism. 18: 2, $157-174$,

Ryan, Peter J. and Hoontrakul, Pongsak. 2012. An Economic Analysis of the Tourism Industry. International Marketing Implications. 9/11, pp 1-26

Polonsky, M. J. 2010. A Stakeholder Theory Approach to Designing Enviromental Marketing Strategic, Journal of Business and Industrial Marketing, 10(3),29-46

Rice, G. 2006. Individual values, organizational context, and self-perceptions of employee creativity. Journal of Business Research, 59(2), 233-241.

Rivera, J. 2004. Institutional pressures and voluntary environmental behavior in developing countries. Society and Natural Resources, 17, 779-797.

Rivera, J., \& de Leon, P. 2005. Chief executive officers and voluntary environmental performance for sustainable tourism. Policy Sciences, 38(2-3), 107-127. 
Ranchhod A. \& Gurau C. 2007. Marketing Strategies: A Contemporary Approach. New Jersey: Prentice Hall

Uma Sekaran. 2006. Metodologi Penelitian Bisnis. Edisi 4. Salemba Empat. Jakarta - hlm 194

Shaalan, I.M. 2005. Sustainable tourism development in the Red Sea of Egypt threats and opportunities. Journal of Cleaner Production, 13(2), 83-87.

Souiden, N., Kassim, N. M., and Hong, H-J. 2006. The Effect of Corporate Branding Dimensions on Consumers' Product Evaluation. Journal of Marketing, 40, 825-845.

Sutrisno Hadi, 2002. Buku Manual Penggunaan SPSS. Paket Midi. Yogyakarta: UGM. hlm $111 \& 113$

Tzschentke, N., Kirk, D., \& Lynch, P.A. 2004. Reasons for going green in serviced accommodation establishments. International Journal of Contemporary Hospitality Management, 16(2), 116-124.

Vincent Gaspersz. 1991. Ekonomitrika Terapan 2. Bandung: Tarsito. hlm $35 \& 10$ 